\title{
Estimation of Natural Radioactivity in Water and Soil in Some Villages of Irbid City
}

\author{
Abdullah I. Mohammad ${ }^{1} \&$ Nabil N. Al-Zubaidy ${ }^{2}$ \\ ${ }^{1}$ Department of Basic Sciences, AL-Huson University College, AL-Balqa’ Applied University, Irbid, AL-Huson, \\ Jordan \\ ${ }^{2}$ Department of Applied Science, Faculty of Engineering Technology, Al-Balqa Applied University, Amman, \\ Jordan \\ Correspondence: Abdullah I. Mohammad, Department of Basic Sciences, AL-Huson University College, \\ AL-Balqa' Applied University, Irbid, PO Box 50, AL-Huson 21510, Jordan. Tel: 962-775-609-740. E-mail: \\ Ab.ib_edu@yahoo.com
}

Received: May 2, 2012 Accepted: May 18, 2012 Online Published: July 16, 2012

Doi: 10.5539/apr.v4n3p39

URL: http://dx.doi.org/10.5539/apr.v4n3p39

\begin{abstract}
This study presented the results of measurements of radon gas (Rn-222) in the air of soil and water in the villages of Al-Rafid and Aqraba (north of Jordan) by using solid state nuclear track detectors (SSNTD's), that commercially known as, (CR-39). About 160 detectors were placed in soil of two villages at $40 \mathrm{~cm}$ depth. Soil planted detectors were gathered 17 days past plantation. In addition, the study presented the results of measurements of radon concentration in water of springs, wells and drinking water obtained from networks. We conducted a study of radon concentrations in the water through 220 samples of water from the study area (Al-Rafid and Aqraba villages). The retrieved detectors were chemically etched using $\mathrm{KOH}$ solution of $30 \%$ concentration at temperature of $70{ }^{\circ} \mathrm{C}$ for 8 hours. The alpha track density on the surface of (CR -39) detectors was measured using an optical microscope at proper magnification. It was found that the concentration of radon in Al-Rafid soil were 1.76, 5.0, 4.8 and $2.03 \mathrm{kBq} / \mathrm{m}^{3}$ in zones of East, West, North and South, respectively. While the average radon concentrations in soil zones of Aqraba village were $2.0,7.1,6.01$ and $3.7 \mathrm{kBq} / \mathrm{m}^{3}$ in East, West, North and South, respectively. In general we note the relatively high concentrations of radon in the air of soil in the study area and the reason that this study conducted in the winter, which is characterized by a lack of drought, high humidity and low temperatures that reduces the opportunity for good ventilation rates.

The study also provided the results of measurements of radon in the waters of Al-Rafid and Aqraba villages. The highest concentration of radon in spring's water of Al-Rafid village was in Busta spring and the lowest concentration in Al-Rafid spring, while the average radon in Aqraba spring was $2.6 \mathrm{~Bq} / \mathrm{L}$. The radon concentration in water wells of Al-Rafid village was ranged from $1.8 \mathrm{~Bq} / \mathrm{L}$ in East zone to $5.3 \mathrm{~Bq} / \mathrm{L}$ in West zone. However, the results showed that the radon concentrations in wells of Aqraba village were highest from radon concentration in wells of Al-Rafid village, while the concentrations were 2.7, 6.3, 5.5 and 4.0 Bq/L in zones of East, West, North and South, respectively. The average radon concentration in drinking water obtained from networks in Al-Rafid village was $1.8 \mathrm{~Bq} / \mathrm{L}$ which is less than average radon concentration in water obtained from networks in Aqraba village $2.4 \mathrm{~Bq} / \mathrm{L}$. Concentration of radon in the water within the limits of international.
\end{abstract}

Keywords: radioactivity, radon soil, radon water, Irbid city, Jordan

\section{Introducation}

\subsection{Radon in Soil}

Soil is the main source of radon gas, the gas concentration may vary from zone to another zone and increase with the depth below surface of the earth (Shweikani \& Durrani, 1995; Al-Jundi, Al-Bataina, Abu-Rukah, \& Shehadeh, 2003; Mohammad \& Abumurad, 2008; Nabil \& Abdullah, 2011, 2012; Al-Zubaidy et al., 2012), if radon can not leak into the air it stays with soil. Physical characteristics of soils and rocks have a significant role in determining the concentration of radon gas because they contain elements uranium and thorium in rocks acid ratios greater than in the basal rocks. Also found that, the cracks and faults working to increase the flow of radon and other gases from the earth to the surface layers. As mentioned radon concentration depends on the depth of 
soil, water content and porosity where the higher of effective porosity (permeability) increase the spread of radon gas, so the spread in the sand more than in the silt and clay. Also radon depends on the weather factors such as wind speed, relative humidity, rainfall and temperature. All these factors are affected by air pressure (decrease in air pressure means increase the flow of radon from the soil) (Shweikani \& Durrani, 1995). Soil and rocks contain on many of the radioactive elements such as radium and uranium compounds in addition to radon gas in the air of the soil.

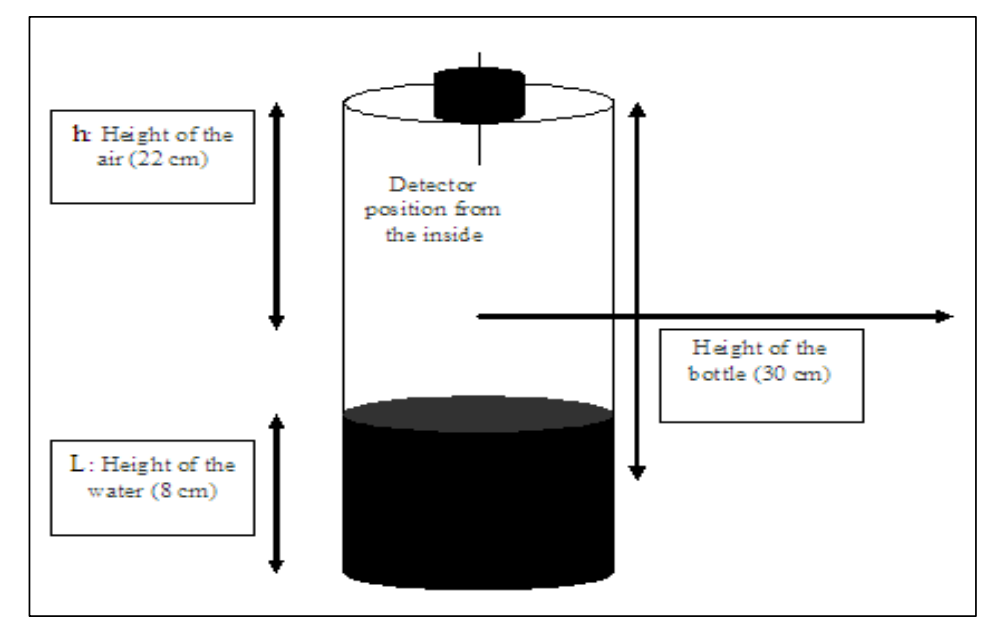

Figure 1. Illustration shows how to use the detector in measurement of radon concentration in water

To calculate the flow rate of radon from the soil $\left(\mathrm{J}_{1}\right)$ using, the following relations (Singh \&Virk, 1996):

$$
\begin{gathered}
J_{1}=-D_{0} \frac{\partial C}{\partial Z}\lfloor z-0 \\
D_{0}=D P
\end{gathered}
$$

Where,

$D_{e}$ : The effective diffusion coefficient of radon $\left(\mathrm{m}^{2} \cdot \mathrm{sec}^{-1}\right)$.

$C$ : Radon gas concentration $\left(\mathrm{Bq} \cdot \mathrm{m}^{-3}\right)$.

$Z$ : depth of soil (m).

$J_{l}$ : amount of radon flow $\left(\mathrm{Bq} \cdot \mathrm{m}^{-2} \cdot \mathrm{sec}^{-1}\right)$.

$D$ : diffusion coefficient of radon from the soil $\left(\mathrm{m}^{2} \cdot \mathrm{sec}^{-1}\right)$.

$P$ : Porosity.

Diffusion of radon through the soil is given by the following relationship:

$$
\frac{D_{0}}{P} \frac{d^{2} c}{d Z^{2}}-\lambda C+\beta=0
$$

Where,

$\lambda$ : Decay constant $\left(\mathrm{sec}^{-1}\right)$.

$\beta$ : a constant associated with emission rate $\left(\mathrm{Bq} \cdot \mathrm{m}^{-3} \cdot \mathrm{sec}^{-1}\right)$.

For the purpose of simplification, diffusion of radon is without a source of radon $(\beta=0)$. Therefore, equation (3) becomes as follows:

$$
\frac{D_{0}}{P} \frac{d^{2} c}{d Z^{2}}-\lambda C=0
$$

Solving for Equation (4), we have: 


$$
C(Z)=C_{0} \exp \left\{-\left[\frac{\lambda P}{D_{0}}\right]^{\frac{1}{2}} Z\right\}
$$

Where:

$C(z)$ : Radon concentration at a depth (z) below the surface of the earth at any time.

$C_{0}$ : Radon concentration at the surface of the soil.

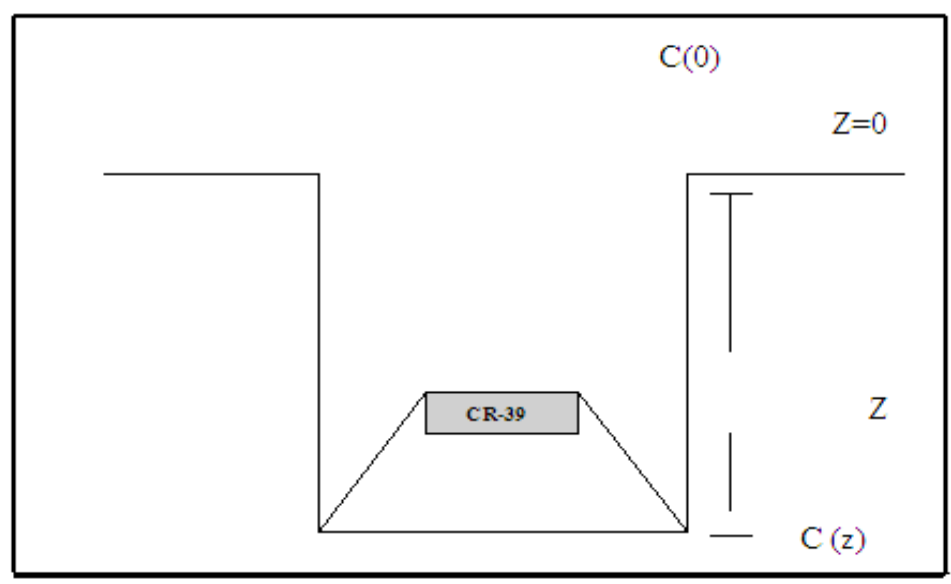

Figure 2. Illustration shows how to use the detector in measurement of radon concentration in the soil

\subsection{Radon in Water}

Rain is formed two types of water; water seeping into the ground is called the ground water and water remain on the surface is called the surface water. These types contribute to the transfer of radon to the air, when radon is dissolved in water. Surface water contribute in the transfer of radon to the air, turning the concentration of gas in the air, which is exposure to this gas through the processes of drinking water or breathing the gas where it enters the bodies of organisms. Jordan relies significantly on groundwater as a source of a major supply of water and this water contains large amounts of dissolved radon gas, which depending on the depth at which there is a groundwater and the nature of the rocks contain (Al-Jundi et al., 2002; Ajlouni, Abdelsalam, Abu-Haija \& Joudeh, 2009; Ajlouni, Abdelsalam, Abu-Haija \& Almasa'efah, 2010; AL-Amairyeen et al., 2010). Exposed organism when drinking from groundwater to the massive doses of radiation more than drinking water obtained from the water networks in major cities.

Table 1. Some results of studies to measure the concentrations of radon in the water and soil of Jordan

\begin{tabular}{|c|c|c|c|}
\hline Study site & Average & Notes & Reference \\
\hline \multirow[t]{3}{*}{ Jordan } & $3.2-5.5(\mathrm{~Bq} / \mathrm{L})$ & Hot water springs & \multirow{3}{*}{$\begin{array}{l}\text { Al-Bataina, Ismail, Kullab, Abumurac } \\
\text { and Mustafa (1997) }\end{array}$} \\
\hline & 4.3-6.4 (Bq/L) & Sea water & \\
\hline & 2.5-4.7 (Bq/L) & Drinking water & \\
\hline Jordan / & $22.4(\mathrm{~Bq} / \mathrm{L})$ & Spring water & \multirow{2}{*}{$\begin{array}{l}\text { Al-Bataina, Tarawneh and Latifeh } \\
\text { (2003) }\end{array}$} \\
\hline Aggreate & $3.3-10.7(\mathrm{~Bq} / \mathrm{L})$ & Cold water springs & \\
\hline Jordan / Irbid & $4.00 \mathrm{kBq} / \mathrm{m} 3$ & $\begin{array}{l}\text { Limestone at a depth of } \\
100 \mathrm{~cm}\end{array}$ & $\begin{array}{c}\text { Abumurad, Atallah, Kullab, and } \\
\text { Ismail (1997) }\end{array}$ \\
\hline Jordan/ & Range (0.2-0.3) & At a depth of $30 \mathrm{~cm}$ & Al-Bataina and Abd-Elmoniem \\
\hline AlZarqa & To $(0.3 \pm 4.8) \mathrm{kBq} / \mathrm{m}^{3}$ & & $(2003)$ \\
\hline
\end{tabular}


To calculate the concentration of radon in water samples, we will use the following equation (See Figure 1):

$$
C_{w}=C_{a}\left(\frac{\lambda h t}{L}\right)
$$

Where,

$c_{w}:$ Radon gas concentration in sample water $\left(\mathrm{Bq} / \mathrm{m}^{3}\right)$ or $\mathrm{Bq} / \mathrm{L}$.

$c_{a}$ : Concentration of radon in the air above the water sample $\left(\mathrm{Bq} / \mathrm{m}^{3}\right)$ or $\mathrm{Bq} / \mathrm{L}$.

$\lambda$ : Decay constant of radon gas and is equal to $0.1814 \mathrm{~d}^{-1}$.

$\mathrm{h}$ : high detector from the surface of the water $(\mathrm{cm})$.

t: Time exposing the detector to sample the water in days.

L: Height of the water inside the bottle $(\mathrm{cm})$.

Studies conducted all over the world to measure the level of radon in the water and the soil, where found that the concentration of radon in groundwater depends on the type of water source. In Jordan, several studies conducted to measure the concentrations of radon gas (See Table 1).

In the present study (Al-Rafied and Aqraba villages), we measured the radon concentration in the soil at a depth of $40 \mathrm{~cm}$ and radon concentration in four springs, wells and drinking water obtained from networks. Almost, each house in the study area has a well built by the owner of the house to store rainwater and use when needed, also Al-Rafid village contains three springs called (Al-Rafid spring, Busta spring and Um-Arshied spring), while there is one spring in Aqraba village called (Aqraba spring). Every village in the study area was divided into four zones (east, west, north and south) from the center and we took random samples to study radon concentrations in soil, wells and drinking water obtained from networks. Springs were distributed according to their location in the study area, where in Al-Rafid village there was Al-Rafid spring in the east zone and Um-Arshied spring in the north zone while, Busta spring in west zone. In Aqraba village there was only one spring known as Aqraba spring which is located in south zone.

\section{Measuring Procedures}

A Passive integrated Radon Dosimeter was used to measure radon levels in soil and water of study area (Al-Rafid and Aqraba villages). Dosimeter consists of a plastic box installed inside the solid state detector; detector size is small and the shape of a square whose sides measure $1.5 \mathrm{~cm}$. A detector is installed in the bottom of the box by adhesive tape double sided and drilling a particular number on the top right corner of the detector in order to facilitate the collection of detectors and the face that contains the number to the top. After that the box is closed by a plastic cover has a circular hole diameter of $1.5 \mathrm{~cm}$ covered the hole with a piece of sponge thickness $(0.5 \mathrm{~cm})$ allows this piece to enter the radon mixed with air soil and prevent the entry of dust into the box and impede the leakage of other isotopes of radon, especially Thoron gas into the dosimeter (See Figure 1).

\subsection{Springs, Wells and Water Obtained from Networks}

We studied the concentration of radon in the water of springs named as (Al-Rafid spring, Busta spring, Um-Arshied spring, Aqraba spring), wells and drinking water obtained from networks. Water was etched in the laboratory, where we bring 220 plastic bottle of the same type (liter and a half of each bottle). We divided the water samples on these bottles (20 samples from springs, 100 samples from wells and 100 sample of drinking water obtained from networks), installed detectors CR-39 on the inner face of the bottle cover and stored half a liter of each sample of water inside the bottle, left the samples for 60 days from the date $(01 / 02 / 2012)$ to $(01 / 04 / 2012)$. After 60 days the collected dosimeters were chemically etched under the conditions $(30 \%$ solution of $\mathrm{KOH}$ at a temperature of $70 \mathrm{C}^{\circ}$ for $8 \mathrm{~h}$ ). An optical microscope was used to count track densities on the detectors surfaces.

\subsection{The Soil}

To study the concentration of radon in the soil, we made a hole in the garden of each house at $40 \mathrm{~cm}$ in depth. The house was chosen randomly and one dosimeter was planted in each hole (See Figure 2). Dosimeters planted were left about 17 days and then collected for chemical treatment. Chemical treatment here was the same method of treatment that was used to measure the concentration of radon in water.

\section{Result and Discussions}

Each village in the study area was divided into four zones, in Al-Rafid village named as (east, west, north and 
south), and in Aqraba village the zones named as (east, west, north and south). About 80 dosimeters were planted in each village at $40 \mathrm{~cm}$ depth (See Table 2).

Table 2. Number of dosimeters planted in the soil, collected, lost and percentage of lost dosimeters

\begin{tabular}{ccccc}
\hline Region name & $\begin{array}{c}\text { Distributed } \\
\text { number }\end{array}$ & $\begin{array}{c}\text { Collected } \\
\text { number }\end{array}$ & $\begin{array}{c}\text { Lost number } \\
\text { Percentage of lost } \\
\text { dosimeters (\%) }\end{array}$ \\
\hline East Al-Rafid & 20 & 18 & 2 & 10 \\
West Al-Rafid & 20 & 15 & 5 & 25 \\
North Al-Rafid & 20 & 13 & 7 & 35 \\
South Al-Rafid & 20 & 16 & 4 & 20 \\
East Aqraba & 20 & 16 & 4 & 20 \\
West Aqraba & 20 & 14 & 6 & 30 \\
North Aqraba & 20 & 20 & 0 & 0 \\
South Aqraba & 20 & 16 & 4 & 20 \\
Total & 160 & 128 & 32 & 20 \\
\hline
\end{tabular}

\subsection{Result and Discussions in Soil of the Study Area}

Table 3 shows different concentration of radon in the air of soil by villages and zones of the same village, while the high concentrations were in West and North zones compared with other zones in Al-Rafid village, because soil characterized by excellent porosity, high thickness and low humidity allowing for the radon to exist freely in the soil for long periods. Concentrations in soil of East and South zones were few compared with the concentrations of West and North zones in the village of Al- Rafid, The reason is due to the gardens of these zones contain irrigated crops were blocked pores between soil particles with water (See Figure 3).

Table 3. Different concentrations of radon $\left(\mathrm{kBq} / \mathrm{m}^{3}\right)$ in the air of soil in zones of the study area

\begin{tabular}{cccc|cccc}
\hline \multicolumn{3}{c}{ Al-Rafid } & village & \multicolumn{4}{c}{ Aqraba village } \\
\hline $\begin{array}{c}\text { Region } \\
\text { name }\end{array}$ & Minimum & Maximum & Average & $\begin{array}{c}\text { Region } \\
\text { name }\end{array}$ & Minimum & Maximum & Average \\
\hline East & 0.69 & 4.16 & 1.76 & East & 0.8 & 3.95 & 2.0 \\
West & 1.56 & 8.7 & 5.0 & West & 2.5 & 10.3 & 7.01 \\
North & 1.9 & 14.7 & 4.8 & North & 3.4 & 12.7 & 6.1 \\
South & 1.06 & 4.9 & 2.03 & South & 1.5 & 6.8 & 3.7 \\
\hline
\end{tabular}

The second location of the study area is Aqraba village (See Table 3). The high concentrations of radon were in West and North zones. Rocks down the soil of these zones of Aqraba village contain uranium, which helps to increase the concentration of radon in the soil. Also, the reason for this is due to the fact that these two zones higher than other zones in Aqraba village (See Fig 3). Population of East and South is working on tilling the ground and continuously for agriculture leading to turn the soil allows air exchange between soil and atmosphere and this contributes to reduce the concentration of gas in the soil. 


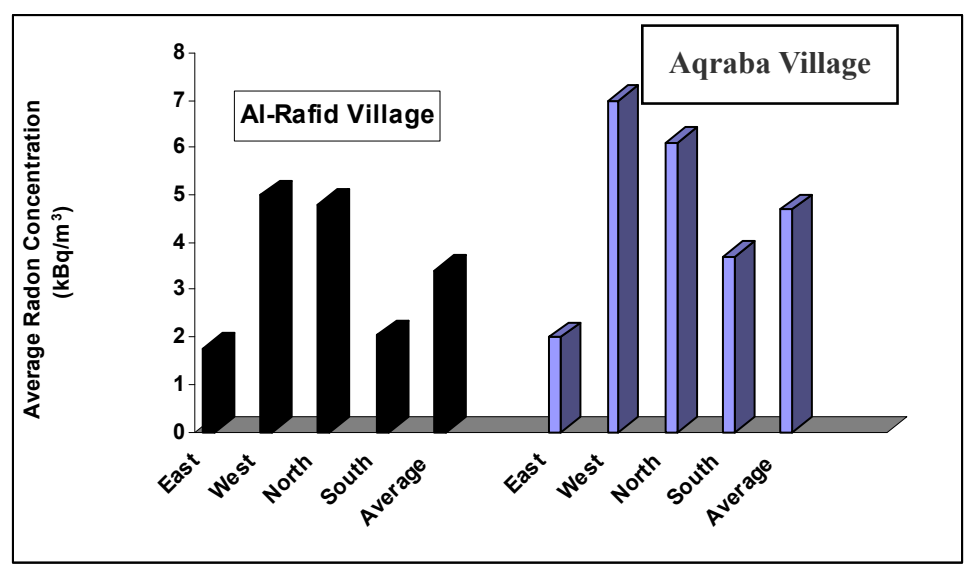

Figure 3. Comparison between the concentrations of radon in the air of soil in zones of the study area

For the purpose of the study to be comprehensive, we studied the concentration of radon in spring water, wells and water obtained from networks, where we bring different samples of different types of water.

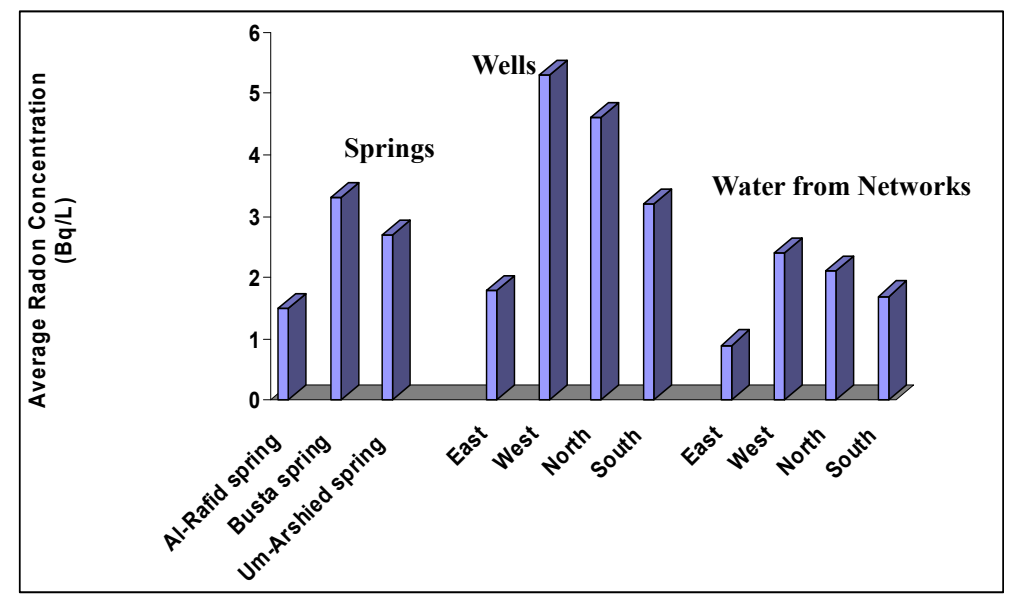

Figure 4. Comparison between the concentrations of radon in springs, wells and water from networks in zones of Al-Rafid village

\section{2 Result and Discussions in Water of the Study Area}

We found that the overall average concentration of radon in spring's water of Al-Rafid village was equal to 2.43 $\mathrm{Bq} / \mathrm{L}$, where the average was the highest concentration of radon in water of Busta spring $3.3 \mathrm{~Bq} / \mathrm{L}$ (See Table 4). The highest concentration of radon in wells of Al-Rafid village was $5.3 \mathrm{~Bq} / \mathrm{L}$ in West zone and the lowest 1.8 $\mathrm{Bq} / \mathrm{L}$ in East zone, while average radon concentration in water obtained from networks in Al-Rafid village ranged from $0.9 \mathrm{~Bq} / \mathrm{L}$ in East zone to $2.4 \mathrm{~Bq} / \mathrm{L}$ in West zone (See Figure 4). 
Table 4. Average radon concentrations $(\mathrm{Bq} / \mathrm{L})$ in springs, wells and water obtained from networks in Al-Rafid village

\begin{tabular}{|c|c|c|c|c|c|}
\hline \multicolumn{2}{|c|}{ Sprigs Al-Rafid village } & \multicolumn{2}{|c|}{ Wells of Al-Rafid village } & \multicolumn{2}{|c|}{ Water obtained from networks in Al-Rafid village } \\
\hline Spring Name & Average & Region Name & Average & Region Name & Average \\
\hline Al-Rafid spring & 1.5 & East & 1.8 & East & 0.9 \\
\hline Busta spring & 3.3 & West & 5.3 & West & 2.4 \\
\hline \multirow[t]{2}{*}{ Um-Arshied spring } & 2.7 & North & 4.6 & North & 2.1 \\
\hline & & South & 3.2 & South & 1.7 \\
\hline
\end{tabular}

Note that the concentration of radon in the water of Busta spring is greater than concentrations in the other springs in Al-Rafid village, the reason for this is due to the nature of the rocks undergone by the water before rising to the surface, which may even contain a few of the uranium and helps in increasing the concentration of radon gas (See Figure 4). Table 4 shows the average radon concentrations in wells of Al-Rafid village were 1.8, 5.3, 4.6 and 3.2 Bq/L in East, West, North and South zone, respectively. The difference in the concentrations of radon due to many reasons, including the nature of the rocks of the study area (See Figure 4), population of the study area, depth of wells and time of storage water in wells. The average radon concentration in water obtained from networks was less than average radon concentration in springs and wells in Al-Rafid village, the reason is due to leakage of radon from water networks before it reaches homes, also have water tanks on surfaces of houses in the mostly open allowing leakage of radon into the air.

Table 5. Average radon concentrations $(\mathrm{Bq} / \mathrm{L})$ in wells and water obtained from networks in Aqraba village

\begin{tabular}{cc|cc|cc}
\hline \multicolumn{2}{c|}{ Sprigs in Aqraba village } & \multicolumn{2}{|c|}{ Wells of Aqraba village } & \multicolumn{2}{c}{ Water obtained from networks in Aqraba village } \\
\hline \multirow{2}{*}{ Springs Name } & Average & Region Name & Average & Region Name & Average \\
\hline \multirow{3}{*}{} & East & 2.7 & East & 1.6 \\
& & West & 6.3 & West & 3.4 \\
& & North & 5.5 & North & 2.5 \\
Aqraba spring & 2.6 & South & 4.0 & South & 1.9 \\
\hline
\end{tabular}

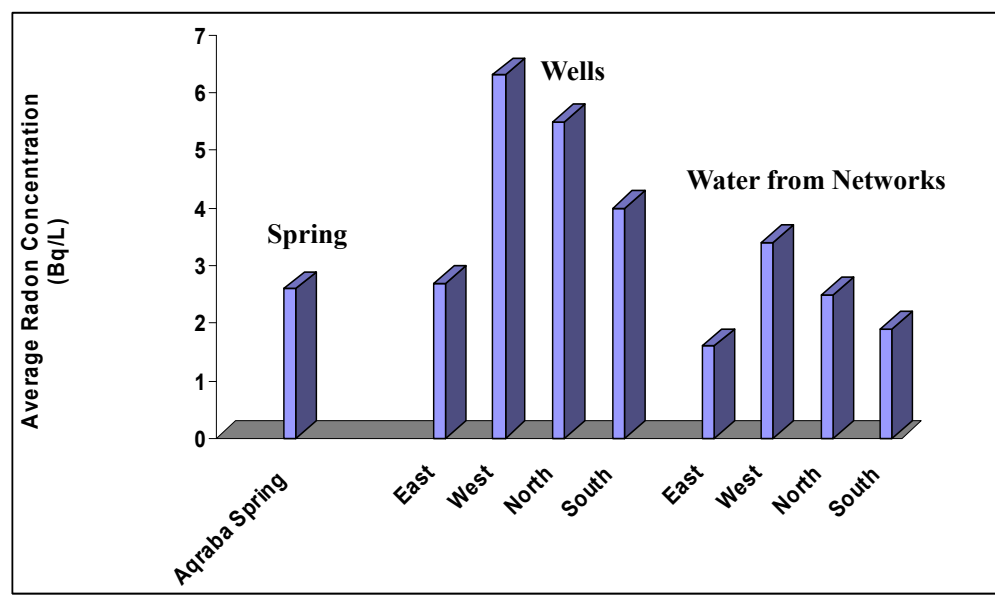

Figure 5. Comparison between the concentrations of radon in spring, wells and water from networks in zones of Aqraba village

The study showed that the radon concentrations in wells of Aqraba village were highest in the zones of West and North (See Table 5), where the advantages of the two zones are the highest concentrations in the soil of these 
zones and the high concentration of radon in the soil contributes to increase the concentration in water wells. Note that there is variation in the concentration of radon in the water areas of the village of Aqraba, Where the concentrations of radon gas is the least in the zones of East and South. Most of houses in the two zones are characterized as a modern. In addition, the people realize the danger of radiation, where they work constantly to detect water tanks to leak radon to the outside. The average radon concentration in Aqraba spring was $2.6 \mathrm{~Bq} / \mathrm{L}$ (See Figure 5).

\section{Conclusions}

The study showed that the average radon concentrations in soil air of Al-Rafid and Aqraba villages were 3.4 and $4.7 \mathrm{kBq} / \mathrm{m}^{3}$, respectively. This is due to the different nature of the soil in the two villages, as well as to the difference in the type of rock under the soil layers to the villages of Al-Rafid and Aqraba.

To be a comprehensive study we examined the water in springs, wells and water obtained from networks. We found that the average radon concentration in springs of Al-Rafid and Aqraba villages was 2.4 and 2.6 Bq/L, respectively. This was due to the nature of the rocks that form underground reservoirs that contain the water in the ground where it may vary from zone to another zone beneath the surface of the Earth. The average concentration of radon in wells of Al-Rafid village was $3.7 \mathrm{~Bq} / \mathrm{L}$, while the average in wells of Aqraba village was $4.6 \mathrm{~Bq} / \mathrm{L}$. This variation of radon concentrations in the wells the of two villages due to several reasons, including the depth of the well, the nature of the rocks beneath the soil, well ventilated, well age, number of residents of the house and their use of the well water.

The average radon concentration in water obtained from networks in Al-Rafid and Aqraba villages was 1.8 and $2.4 \mathrm{~Bq} / \mathrm{L}$, respectively. However; there were appreciable differences between radon concentrations in both villages. This is due to the nature of houses in the study area, water networks (modern or ancient) and ventilation tanks of water that are present on the surface of the building. Concentrations were generally low and do not constitute a risk to residents of the study area. We conclude that the study area is infested area of natural radiation and Concentration of radon in the study area within the limits of international.

\section{References}

Ajlouni, A. W., Abdelsalam, M., Abu-Haija, O., \& Joudeh, B. (2009). New findings: Avery high natural radiation area in Afra hot springs, Jordan. Radiation Protection Dosimetry, 1-4. http://dx.doi.org/10.1093/rpd/ncp028

Ajlouni, A. W., Abdelsalam, M., Abu-Haija, O., \& Almasa'efah, Y. (2010). Radiation doses due tonatural radioactivity in Afra hot spring. Int. J. Low Radia, 7(1). http://dx.doi.org/10.1504/IJLR.2010.032770

AL-Amairyeen, H. (2010). Radiation doses due to natural radioactivity in Wadi Bin Hammad, Al-Karak, Jordan. International Journal of the Physical Sciences, 5(9), 1486- 1488.

Al-Bataina, B., Ismail, A., Kullab, M., Abumurad, K., \& Mustafa, H. (1997). Radon Measurements in Different Types of Natural Waters in Jordan. Radiat. Meas., 28(1-6), 591-594. http://dx.doi.org/10.1016/1350-4487(95)00255-3

Al-Bataina, B., Tarawneh, \& Latifeh, M. S. (2003). Measurement of Radon Concentration in Water and Building Aggreate Samples in Al-Karak, Jordan. Abhath Al-Yarmouk: Basic Sci. Eng. B, 12(1), 221-230.

Al-Bataina, B., Abd-Elmoniem, A., \& Elzain. (2003). Seasonal variation of Indoor Radon-222 Concentration Level in Zarqa city of Jordan. Abhath Al-Yarmouk: Basic Sci. Eng., 12(1), 191-202.

Abumurad, K., Atallah, M., Kullab, M., \& Ismail, A. (1997). Determination of Radon Soil Concentration Levels in the Governorate of Irbid-Jordan. Radon, Meas., 28(1-6), 585-588.

Al-Jundi, J. (2002). Population doses from terrestrial gamma exposure in areas near to old phosphate mine, Russaifa, Jordan. Radiat. Meas., 35, 23-28. http://dx.doi.org/10.1016/S1350-4487(01)00261-X

Al-Jundi, J, Al-Bataina, B. A, Abu-Rukah, Y., \& Shehadeh, H. M. (2003). Natural radioactivity concentration in soil samples along the Amman Aqaba Highway, Jordan. Radiation Measurements, 36, 555-560. http://dx.doi.org/10.1016/S1350-4487(03)00202-6

Mohammad, A., \& Abumurad, K. (2008). Evaluation of radon gas concentration in the air of soil and dwellings of Hawar and Foara villages, using (CR-39) detectors. Radiat. Meas., 43, 452-455. http://dx.doi.org/10.1016/j.radmeas.2008.04.074

Nabil, N. Al-Zubaidy, \& Abdullah, I. Mohammad. (2011). Measurements of Radon Gas Concentrations in Hubras and Harta Villages and Its Effect on Public Health by Application of Nuclear Track Detectors (NTD's). European Journal of Scientific Research. 
Nabil, N. Al-Zubaidy, \& Abdullah, I. Mohammad. (2012). Health Effects on Public of Malka Region due to Radon Gas, Using (CR-39) Detector. Hikari Ltd. Adv. Theor. Appl. Mech., 5(2), 61- 67.

Nabil, N. Al-Zubaidy. (2012). Increse in the Probability of Lung Cancer Disease in Some Homes of Al-Mafraq City, Jordn Caused by Radon. Hikari Ltd. Adv. Theor. Appl. Mech., 5(5), 199-207.

Shweikani, R., \& Durrani, S. A. (1995). The Effect of Soil Parameters on the Radon Concentration Values in the Environment. Radiat. Meas., 25(1-4), 581-584. http://dx.doi.org/10.1016/1350-4487(95)00188-K

Singh, B., \& Virk, H. S. (1996). Effects of Soil and Sand Moisture content on Radon diffusion Using Plastic Track Etched Detector. Radiat. Meas., 26(1), 49-50. Retrieved from http://www.academicjournals.org/IJPS 